\title{
Species of Fragaria L. (Rosaceae) genus of Central, Northern and Eastern Mongolia
}

\author{
Sergey Baturin ${ }^{1}{ }^{*}$, Nasanjargal Tovuudorj ${ }^{2}$, Elena Filipenko ${ }^{1}$, Renchinmyadag Tovuudorj ${ }^{3}$ \\ and Ganbold Jigmed ${ }^{2}$ \\ ${ }^{1}$ Federal Research Center Institute of Cytology and Genetics the Siberian Branch of the Russian \\ Academy of Sciences, 630090 Lavrent'ev av., 10, Novosibirsk, Russian Federation \\ ${ }^{2}$ Mongolian University of Life Sciences, Agronomy and Plant Protection Department, 17024, \\ Ulaabaatar, Mongolia \\ ${ }^{3}$ Institute of Geography and Geo-ecology, Mongolian Academy of Sciences, 15170, Ulaanbaatar, \\ Mongolia
}

\begin{abstract}
Numerous publications of Russian and Mongolian researchers report the only species Fragaria orientalis Losinsk to be typical for Mongolia. However, by generally accepted taxonomy of Fragaria genus, the species $F$. orientalis is a tetraploid $(2 n=4 x=28)$ which occupies a small area within Eastern regions of Russia and North-Western China. To clarify the specific belonging of strawberry, 11 Fragaria samples were collected in Central, Northern and Eastern parts of Mongolia. Species were identified by morphological characters and molecular marker of alcohol dehydrogenase adh1 gene. The results of the specific belonging study in Fragaria samples reveal two diploid species $F$. viridis and $F$. mandshrica growing in Mongolia.
\end{abstract}

\section{Introduction}

Modern taxonomy of Fragaria L. genus includes at least 20 wild species, three spontaneous interspecific hybrids species and two cultivated hybrid species [1-3]. All these species form the polyploid series of Fragaria genus: $2 n=2 x, 4 x, 5 x, 6 x, 8 x$ and $10 x$, where $x=7[4,5]$. The diploid group includes 12 species, namely $F$. vesca L., $F$. viridis Duch., $F$. mandshurica Staudt, $F$. bucharica Losinsk, $F$. iinumae Makino, $F$. nipponica Makino, $F$. nilgerrensis Schlect., F. chinensis Losinska, F. daltoniana J. Gay, F. nubicola Lindl., F. pentaphylla Losinsk и $F$. $\times$ bifera Duch. The diploid species are widespread in SouthEastern Asia: there grow 8 of them in China [6], but also well represented in Siberia and Far East of Russia [7].

Numerous publications of Russian and Mongolian scholars report that $F$. orientalis Losinsk is the only one strawberry species growing in Mongolia [8-13]. However, there are indications to one more species in the Northern part of the country $-F$. viridis Duch. [14], which is also mentioned in the list of plants of Mongolia The Catalogue of Life Partnership [15]. According to generally accepted taxonomy of Fragaria genus, F. orientalis is a

* Corresponding author: $\underline{\mathrm{SO} \text { baturin@mail.ru }}$ 
tetraploid species $(2 n=4 x=28)$ and it occupies a rather small area within Eastern regions of Russia including Primorsky Krai, Khabarovsk Krai, Jewish Autonomous Oblast and Amur Oblast, and of China in Heilongjiang province. In China along the Amur River valley, $F$. orientalis meets with $F$. mandshurica, but different chromosome number prevents hybridization, so mixing of the species does not occur [16]. For Mongolian territory it is accepted to state only $F$. mandshurica growing there [1,6, 16-18]. In this connection, our study aimed to clarify the specific belonging of wild-growing strawberry plant material collected in different aimags of Central, Northern and Eastern Mongolia.

\section{Materials and methods}

Eleven wild growing Fragaria samples collected in Mongolia were studied and included to the Fragaria collection of the Laboratory of Plant selection of Mongolian University of Life Sciences, Ulaanbaatar. Sites of plant collecting are presented in Table 1.

Table 1. List of Fragaria samples.

\begin{tabular}{|c|c|c|c|c|}
\hline № & $\begin{array}{l}\text { Sample } \\
\text { registrat } \\
\text { ion } \\
\text { number }\end{array}$ & Aimag & $\begin{array}{l}\text { Region of } \\
\text { Mongolia }\end{array}$ & $\begin{array}{l}\text { Geographical coordinates of the site } \\
\text { of collecting and alttitude }(\mathrm{H}), \mathrm{m}\end{array}$ \\
\hline 1 & $18-2$ & Ulaanbaatar & Central & N 4752'34", E $106^{\circ} 53^{\prime} 44^{\prime \prime}, \mathrm{H}=1424 \mathrm{~m}$ \\
\hline 2 & $18-3$ & Tuv & Central & $\mathrm{N} 47^{\circ} 39^{\prime} 26^{\prime \prime}, \mathrm{E} 107^{\circ} 43^{\prime} 49^{\prime \prime}, \mathrm{H}=1716 \mathrm{~m}$ \\
\hline 3 & $18-4$ & Ulaanbaatar & Central & $\mathrm{N} 47^{\circ} 52^{\prime} 27^{\prime \prime}, \mathrm{E} 106^{\circ} 53^{\prime} 30^{\prime \prime}, \mathrm{H}=1509 \mathrm{~m}$ \\
\hline 4 & $18-7$ & Arkhangai & Central & $\mathrm{N} 46^{\circ} 21^{\prime} 57^{\prime \prime}, \mathrm{E} 101^{\circ} 42^{\prime} 28^{\prime \prime}, \mathrm{H}=1948 \mathrm{~m}$ \\
\hline 5 & $18-8$ & Arkhangai & Central & $\mathrm{N} 46^{\circ} 21^{\prime} 57^{\prime \prime}, \mathrm{E} 101^{\circ} 42^{\prime 2} 28^{\prime \prime}, \mathrm{H}=1948 \mathrm{~m}$ \\
\hline 6 & $18-9$ & Bulgan & Northern & $\mathrm{N} 49^{0} 28^{\prime} 22^{\prime \prime}$, E $105^{\circ} 06^{\prime} 16^{\prime \prime}, \mathrm{H}=1107 \mathrm{~m}$ \\
\hline 7 & $18-10$ & Bulgan & Northern & $\mathrm{N} 49^{0} 28^{\prime} 22^{\prime \prime}, \mathrm{E} 105^{\circ} 06^{\prime} 16^{\prime \prime}, \mathrm{H}=1107 \mathrm{~m}$ \\
\hline 8 & $18-11$ & Tuv & Central & $\mathrm{N} 48^{\circ} 13^{\prime} 54^{\prime \prime}, \mathrm{E} 106^{\circ} 18^{\prime} 51^{\prime \prime}, \mathrm{H}=1390 \mathrm{~m}$ \\
\hline 9 & $18-12$ & Khentii & Eastern & $\mathrm{N} 48^{\circ} 10^{\prime} 62^{\prime \prime}, \mathrm{E} 108^{0} 57^{\prime} 51 ", \mathrm{H}=1624 \mathrm{~m}$ \\
\hline 10 & $18-13$ & Selenge & Northern & $\mathrm{N} 49^{0} 46^{\prime} 18^{\prime \prime}, \mathrm{E} 107^{\circ} 35^{\prime} 47^{\prime \prime}, \mathrm{H}=761 \mathrm{~m}$ \\
\hline 11 & $18-14$ & Khentii & Eastern & $\mathrm{N} 48^{0} 35^{\prime} 28^{\prime \prime}, \mathrm{E} 110^{0} 30^{\prime} 96^{\prime \prime}, \mathrm{H}=1219 \mathrm{~m}$ \\
\hline
\end{tabular}

In wild-growing Fragaria plants, species were identified with keys and descriptions proposed by G. Staudt [16]. Beyond that, in order to identify the species by biomorphological characters, PCR-fragments of Mongolian samples were compared with the ones of Fragaria representatives growing in wild in Siberian Region: $F$. vesca - sample № 15-7/3 (Irkutsk Region, Slyudyanka; N51³8.104' E10342.160' H=665 м), F. viridis sample № 16-17 (banks of the Kuyum River, Chemalsky District, the Altai Republic; N51 ${ }^{\circ} 31.05^{\prime}, \mathrm{E}^{\circ} 6^{\circ} 02.18^{\prime} \mathrm{H}=486 \mathrm{M}$ ), F. mandshurica - sample № 3 (near the town of Yitulihezhen, Yakeshi, Inner Mongolia, China; N50³0.57', E122 $24.47^{\prime}$ ). Sample № 3 was kindly provided by Prof. J.J. Lei from Fragaria species collection of Shenyang Agricultural University [6]. Botanical distribution maps for species were drawn on ArcView 10.5.

For species identification of wild-growing Fragaria samples from Mongolia, we used gene alcohol dehydrogenase $a d h 1$ as a molecular marker. This is the first protein-coding gene in Fragaria, whose nucleotide sequence was established [19]. For phylogenetic and population researches, high informativeness is provided by application of this gene [2, 21] due to the presence of introns in its structure which are known to be exposed to rapid evolutional changes [20]. To identify the species of wild-growing samples, there were used 
specific primers $a d h-2 \mathrm{~F}$ and $a d h-3 \mathrm{R}$ complementary to $a d h 1$ locus allele of the II linkage group in $F$. vesca, earlier developed and successfully applied in studies on phylogenetic relationships in Fragaria genus [21, 22]. In $F$. vesca genome, nucleotide sequences of an exon and intron of the second allele $a d h 2$ significantly differ from adh 1 allele and that is exactly why application of specific primers to $a d h 1$ allele helps to avoid misamplification with adh2 allele [23].

DNA from strawberry leaves was extracted using Genomic DNA Purification Kit (Fermentas). For PCR, special primers for alcohol dehydrogenase ( $a d h 1)$ were synthesized: $a d h-2 \mathrm{~F} 5$, CCAAGGTACACATTCTTTTTTTC 3 , and $a d h-3 \mathrm{R}$ 5'GTCACCCCTTCACCAACACTCTG 3'. PCR reaction mixture contained: 50-100 ng of plant DNA and $600 \mathrm{nM}$ concentration of primers in a buffer of $65 \mathrm{mM}$ Tris $\mathrm{HCl},(\mathrm{pH} 8.9)$, $24 \mathrm{mM}\left(\mathrm{NH}_{4}\right)_{2} \mathrm{SO}_{4}, 3 \mathrm{mM} \mathrm{MgCl}, 0.5 \%$ Tween 20, and $200 \mu \mathrm{m}$ dNTP, adding Taqpolymerase "hot start" (produced by ICBFM, Sib.Br. of Rus.Sci.Acad.) 1 unit per reaction. After preliminary heating at $95^{\circ} \mathrm{C}$ for $15 \mathrm{~min}$, there followed 30 cycles: $95^{\circ} \mathrm{C}$ for $1 \mathrm{~min}$, $58^{\circ} \mathrm{C}$ for $90 \mathrm{~s}$ and $72^{\circ} \mathrm{C}$ for $1 \mathrm{~min}$. Amplified DNA fragments were separated by electrophoresis in $2 \%$ agarose gel and $1 \mathrm{x}$ TAE buffer.

Chromosome number in seedlings calculation was performed at root tips by staining chromosomes with lacto-propionic orcein [24].

\section{Results and discussion}

In Central, Northern and Eastern Mongolia (Fig. 1), strawberry is a very popular wild berry $[10,11,13]$. Wild strawberry occurs in Khentii, Khangai, Mongol Altai, Mongol Daguur Biosphere Reserve [8].

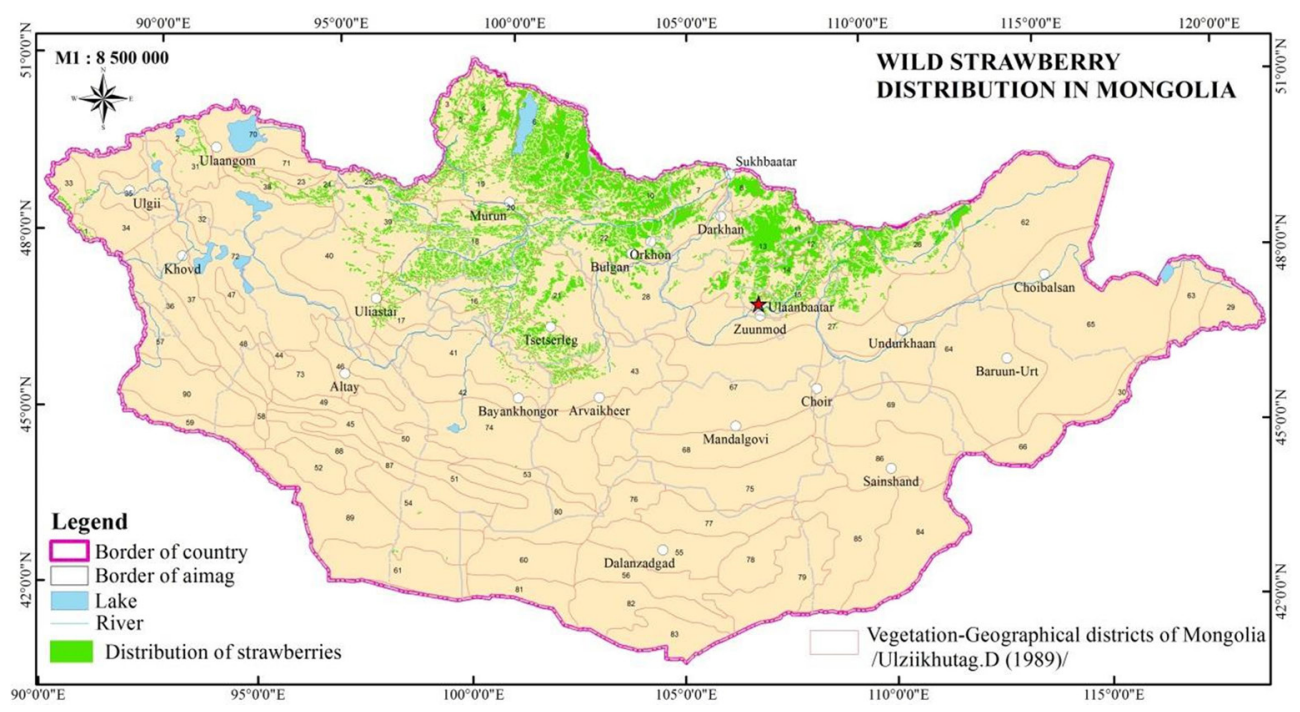

Fig. 1. The wild strawberry distribution in Mongolia.

It grows in 14 of 21 Mongolia's aimags and most widely wild strawberry is spread in Khuvsgul, Bulgan and Selenge aimags comprising the Northern part of Mongolia (Table 2). Distribution of wild strawberry species in Mongolia was mainly taken according to the data of V.I. Grubov [8], which based on the botanical-geographical regionalization made by N. Ulziikhutag [25].

Table 2. The wild strawberry distribution area and percentage in Mongolia. 


\begin{tabular}{|l|c|c|}
\hline \multicolumn{1}{|c|}{ Aimag } & $\begin{array}{c}\text { Area } \\
\left(\mathbf{k m}^{\mathbf{2}}\right)\end{array}$ & $\begin{array}{c}\text { Percentage } \\
\mathbf{( \% )}\end{array}$ \\
\hline Ulaanbaatar & 909.0066 & 0.06 \\
\hline Dornod & 1029.064 & 0.07 \\
\hline Khentii & 9981.921 & 0.64 \\
\hline Tuv & 7958.095 & 0.51 \\
\hline Selenge & 15007.18 & 0.96 \\
\hline Darkhan-uul & 583.1363 & 0.04 \\
\hline Orkhon & 222.9639 & 0.01 \\
\hline Uvurkhangai & 1595.049 & 0.10 \\
\hline Bulgan & 15881.89 & 1.02 \\
\hline Bayankhongor & 497.381 & 0.03 \\
\hline Arkhangai & 10565.06 & 0.68 \\
\hline Khuvsgul & 36566.08 & 2.34 \\
\hline Zavkhan & 8232.512 & 0.54 \\
\hline Bayan-ulgii & 600.2874 & 0.04 \\
\hline Total & 109629.6 & 7.1 \\
\hline
\end{tabular}

In all the collected in Mongolia samples of Fragaria, somatic chromosome number calculation proved them to be diploid, $2 \mathrm{n}=14$. Identification of species by biomorphological characters separated the samples as belonging to two known diploid species: F. mandshurica Staudt and F. viridis Duch. Besides, there were representatives of both species at once in some of collected sample sets. Those were samples № 18-7 and 18-8 from Arkhangai aimag, 18-9 and 18-10 from Bulgan aimag.

The results of specific identification of the samples by alcohol dehydrogenase adh1 gene in studied Fragaria representatives is presented in Fig. 2. There can be clearly seen the specific traits of each Fragaria sample under the study. The electrophoregramme profiles show that for both diploid strawberry species ( $F$. viridis and $F$. vesca), presence of the only one PCR fragment is typical, although, the fragments are significantly different by length. For $F$. viridis typical fragment length is $446 \mathrm{bp}$, while for $F$. vesca - $582 \mathrm{bp}$ (Fig. 2, tracks 1 and 2, correspondingly). That matches the results of earlier studies on phylogeny analysis in Fragaria, including $F$. vesca as well [2]. Moreover, DNA amplified fragments of $F$. viridis and $F$. vesca in our experiment were of the same length as PCR fragments in the study conducted by T. Davis \& al. [22]. Amplification with F. mandshurica DNA also resulted in the only one PCR fragment (Fig. 2, track 3). However, the size of amplified DNA fragment was slightly bigger than of PCR $F$. vesca fragment (Fig. 2, tracks 1 and 3). In comparison to Fragaria species growing in Siberian region, amplification with DNA of wild-growing samples from Mongolia showed the presence of these two species among Mongolian samples. In samples №№ 18-7, 18-8, 18-10, 18-12, and 18-13, the major band of the electrophoregramme is equal by length to the PCR-fragment of $F$. viridis (Fig. 2, tracks $2,7,8,10,12$, and 13), and in №№ 18-2, 18-3, 18-4, 18-9, 18-11, and 18-14 - to the one of $F$. mandshurica (Fig. 2, tracks 3, 4, 5, 6, 9, 11, and 14). Consequently, comparison of amplified fragment profiles of plants from Mongolia testify to the presence of two species $F$. viridis and $F$. mandshurica and that corresponds to the data on identification by bio-morphological characters. 


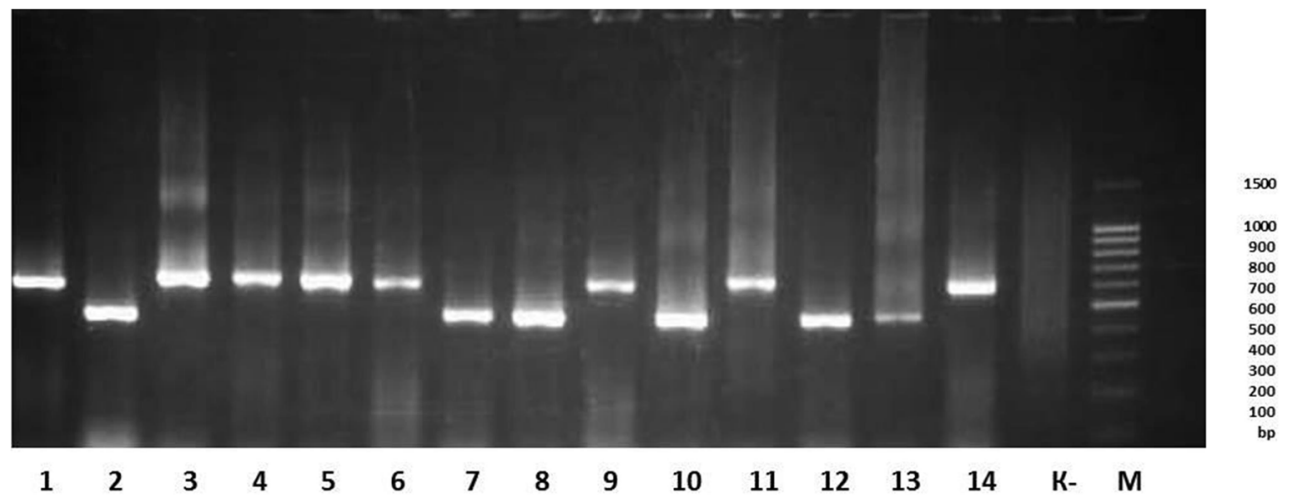

Fig. 2. The electrophoregramme of PCR fragments in $2 \%$ agarose gel. Tracks: $1-F$. vesca; $2-F$. viridis; 3 - F. mandshurica; 4 - № 18-2; 5 - № 18-3; 6 - № 18-4; 7 - № 18-7; 8 - № 18-8; 9 - № 189; 10 - № 18-10; 11 - № 18-11; 12 - № 18-12; 13 - № 18-13; 14 - № 18-14; M - DNA length marker (produced by Evrogen)

Results of the study prove growing of two diploid species $F$. viridis and $F$. mandshurica in the territory of Central, Northern and Eastern Mongolia (Fig. 3). Moreover, representatives of both species can grow side by side, as testified by samples from Bulgan aimag (samples №№ 18-9 and 18-10).

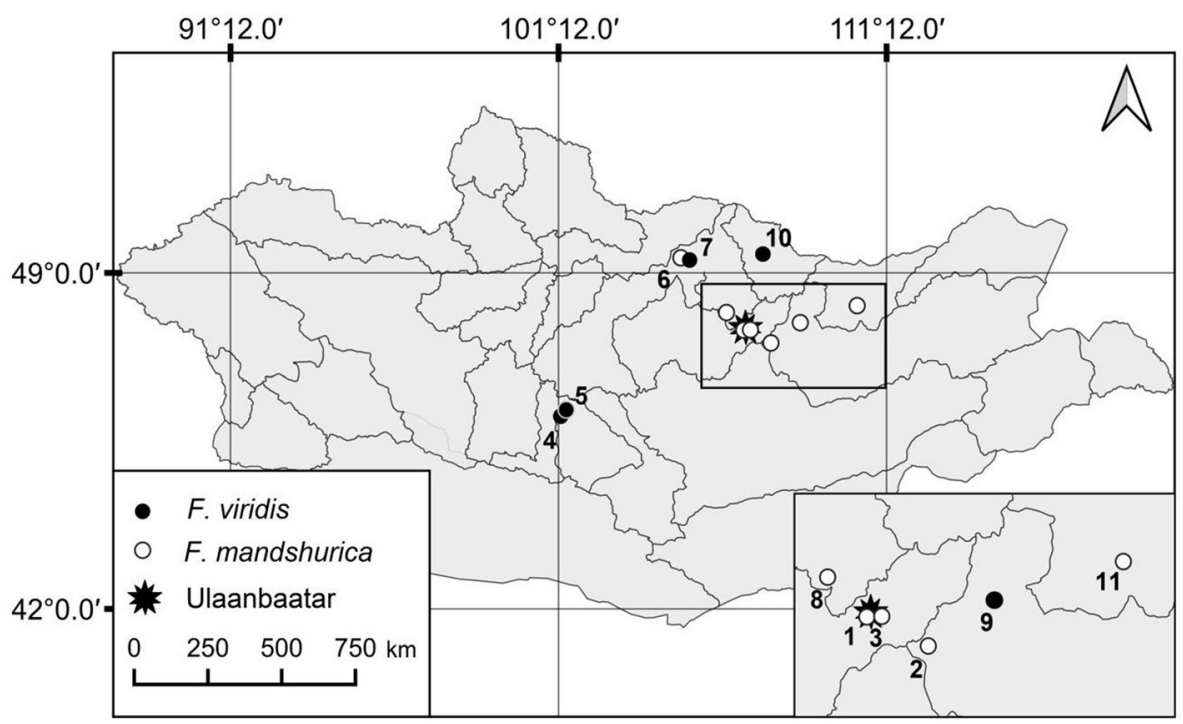

Fig. 3. Distribution of studied Fragaria samples on the map of Mongolia: 1 - № 18-2; 2 - № 18-3; 3 № 18-4; 4 - № 18-7; 5 - № 18-8; 6 - № 18-9; 7 - № 18-10; 8 - № 18-11; 9 - № 18-12; 10 - № 18-13; 11 - № 18-14.

$F$. viridis and $F$. mandshurica growing in Mongolia does not contradict the data of English-language literature $[1,13,14,15,16,17]$. On the contrary, publications in Russian and Mongolian languages mention $F$. orientalis instead of $F$. mandshurica. The problem of confusion of these two specific names is the central focus of a large experimental paper by G. Staudt [16] and he clearly shows the difference between $F$. mandshurica and $F$. orientalis and points their areas. Such a mistake in F. mandshurica identification in the territory of Mongolia is caused by similarity of many morphological characters used for 
specific identification due to phylogenetic closeness of these species. G. Staudt $[16,17,18]$ supposed $F$. orientalis to be a tetraploid descendant of $F$. mandshurica. However, molecular-genetical analysis testifies that $F$. mandshurica is one of the three potential diploid donors along with $F$. vesca and probably, $F$. bucharica [26]. And yet, RFLP analysis of chloroplast DNA refutes the fact that $F$. mandshurica is a mother donor of $F$. orientalis [27]. Nevertheless, the main morphological character to distinguish $F$. mandshurica and $F$. orientalis is flower type: flowers of $F$. mandshurica are monoclinous, while in the form of $F$. orientalis flowers dioecy is realized; main cytological characters, in turn, are diploid chromosome number $(2 n=14)$ and less in size pollen grains in $F$. mandshurica [16]. Analysis of ability to crossing between F. mandshurica (samples collected in Yakutia) and $F$. orientalis revealed reproductive isolation of the two species, as very few seeds developed and the seedlings grown from obtained scarce seeds all turned to be triploid and consequently, sterile [7].

Thus, our study on specific belonging of Fragaria samples from Central, Northern and Eastern parts of Mongolia proves growing of two diploid species $F$. viridis and $F$. mandshurica there.

Authors are grateful to Prof. J.J. Lei for kindly provided standard F. mandshurica Staudt sample from Fragaria species collection of Shenyang Agricultural University. The authors sincerely thank Tatyana Kolomiychuk for the translation of this article. This study was conducted according to budget project RF № 0324-2019-0039-C-01.

\section{References}

1. K. E. Hummer, N. Bassil, W. Njuguna, Wild Crop Relatives: Genomic and Breeding Resources, Temperate Fruits (Springer-Verlag, Berlin Heidelberg, 2011) 17-44

2. L. M. DiMeglio, G. Staudt, H. Yu, T. M. Davis, PLoS ONE, 9, 7 (2014)

M. K. Sobczyk, The Genomes of Rosaceous Berries and Their Wild Relatives (Springer International Publishing AG, part of Springer Nature, 2018) 11-23

3. M. Rousseau-Gueutin, A. Gaston, A. Aïnouche, M. L. Aïnouche, K. Olbricht, G. Staudt, L. Richard, B. Denoyes-Rothan, Mol. Phylogenet. Evol, 51, 515-530 (2009)

4. O. K. Kamneva, J. Syring, A. Liston, N. A. Rosenberg, BMC Evolutionary Biology. 17, 180 (2017)

5. J. J. Lei, L. Xue, H. P. Dai, M. Q. Deng, Acta Horticult. 1049, 289-294 (2014)

6. N. B. Sukhareva, Apomixis and its meaning for evolution and selection, 30, 165-175 [in Russian]

7. V. I. Grubov, Identification Guide of the Vascular Plants of Mongolia (with atlas) (The Science, Leningrad, 1982) 443 [in Russian]

8. R. V. Kamelin, I. A. Gubanov, Sh. Dariymaa, E. Gandbold., Botancal Journal, 77, 4, 10-21 (1992) [in Russian]

9. N. Altansukh, Mongolia: country report to the FAO international technical conference on plant genetic resources, (Leipzig, 1996)

10. D. Damiran, Circular of Information No. 3. (Union, OR, USA: Eastern Oregon Agricultural Research Center, 2005)

11. Ch. Dulamsuren, M. Hauck, M. Mühlenberg, IAVS, Applied Vegetation Science 8, 149-154 (2005)

12. U. Magsar, O. Kwon, B. Badamdorj, K. Nyamsuren, I. Tuvshintogtokh, N. Batkhuu, M. Tovuudorj, S. Khadbaatar, O. Batlai, Y. Cho, J. Pak, M. Kim, S. Choi, H. Kang, H. 
Lkhavgadorj, Introduction. The Handbook for Traditional Knowledge on Biological Resources. Mongolia, 1, 631 (2015)

13. I. A. Gubanov, Systematic Notes on Flora of Outer Mongolia, Vascular Plants (VALANG, Moscow, 1996) 136 [in Russian]

14. M. Hassler, Species 2000 \& ITIS Catalogue of Life, 2019 Annual Checklist (Naturalis, Leiden, the Netherlands, 2019) http://www.catalogueoflife.org/annual-checklist/2019

15. G. Staudt, Bot. Jahrb. Syst. 124, 397-419 (2003)

16. G. Staudt, Acta Horticult. 265, 23-33. (1989)

17. G. Staudt, Acta Horticult. 842, 71-84 (2009)

18. D. J. Wolyn, G. Jelenkovic, Plant Mol. Biol. 14, 855-857 (1990)

19. R. L. Small, R. Cronn, J. F. Wendel, Aust. Syst. Bot. 17, 145-170 (2004)

20. G. Staudt, L. M. DiMeglio, T.M. Davis, P. Gerstberger, Bot. Jahrb. Syst. 125, 53-72 (2003)

21. T. M. Davis, H. Yu, J. Hered. 88, 215-221 (1997)

22. T. M. Davis, M. E. Shields, Q. Zhang, D. Tombolato-Terzic', J. L. Bennetzen, A. Pontaroli, H. Wang, Q. Yao, P. Sanmiguel, K. Folta, BMC. Plant Biol. 10, 81 (2010)

23. N. Preeda, T. Yanagi, K. Sone, S. Taketa, N. Okuda, Scientia Hort. 114, 133-137 (2007)

24. N. Ulziikhutag. Survey of vascular plant of Mongolia (Ulsiin Khevleliin Gazar, Ulaanbaatar, 1989)

25. O. K. Kamneva, J. Syring, A. Liston, N. A. Rosenberg, BMC Evolutionary Biology. 17, 180 (2017)

26. W. Njuguna, Development and Use of Molecular Tools in Fragaria (Oregon State University, 2010) 